\title{
A MODEL FOR PLANNING, IMPLEMENTING AND EVALUATING CLIENT-CENTERED IT EDUCATION
}

\author{
The Third Task of the University Calls
}

Ilkka Kamaja and Juha Lindfors

Department Research Methodology, University of Lapland

\begin{abstract}
The Department of Research Methodology at the University of Lapland is developing a model for the planning, implementation and evaluation of education in the field of Information Technology (IT). The model draws on the concept of client-centeredness, and makes use of regional cooperation in order to carry out the universities' third task. The principal method used in the research is a constructive approach. The model is being developed, and its usability evaluated, in the context of two extensive degree programs at the Department of Research Methodology.
\end{abstract}

Key words: educational planning, information technology, client-centeredness

\section{INTRODUCTION}

The University of Lapland, the northernmost such institution in the European Union, is located in the city of Rovaniemi, an international, growing centre of business, administration and education. The University is one of a number of educational institutions in the area. Although it is a comparatively small (3500 students) and young university (founded in 1979), it has internalised its mission as an important regional actor. The University provides higher education in the fields represented by its four faculties - Law, Education, the Social Sciences and Art and Design - as well as in Information Technology (IT).

IT is taught in the Department of Research Methodology, which forms part of the unit known as Common Education Services. Teaching in IT commenced in 1997, and since then the course offerings in the subject have 
grown rapidly into a full degree programme. IT cannot be studied as a major subject at the University however, and the master's programmes have been established as a solution to overcome this problem.

The first masters' programme commenced in 2000 (ITMO) and the second (NetCom) in 2002. The idea behind these programmes is that students complete a major ( 82.5 credits) in one of the faculties and take further studies (82.5 credits) equivalent to a major in IT. The resulting programme, in particular the master's thesis, is cross disciplinary, focusing on IT applications in the subjects taught in the faculties.

The following sections describe the aims of the model for the planning, implementation and evaluation of client-centered education, provide background to the research, and present a preliminary model.

\section{A CLIENT-CENTERED APPROACH}

\subsection{Background to the research}

Society today has many hopes, expectations and, indeed, demands where university-level education is concerned. University education is often criticized as being excessively theoretical and detached from the needs of working life. Only a limited number of graduates pursue careers as university researchers; most go to work in the public sector or the business world. Yet working life needs, and places value on, many of the goals of a university education. A survey conducted as part of the NetCom project indicates that businesses in the ICT sector value the following:

- a capacity for broad-based theoretical thinking and the ability to examine things within frames of reference;

- the conceptualizing and solving of problems;

- managing and directing projects;

- working at the client interface.

The traditional function of the universities, one set out in law, is to carry out scientific research and to provide higher education that is grounded in that research. Today we see an emphasis on what is known as the 'third task' of universities - one essential element of which is regional effectiveness. Universities are seen as dynamos or motors for their region, with a key role ascribed to their societal effectiveness and interaction with cultural, working and business life. The degree-oriented, academic education has been joined by education that is derived directly from the needs of working life (Sallinen, 2000; ja Virtanen, 2002). 


\subsection{Goals of the research}

Regional effectiveness is one of the central strategic goals of the University of Lapland. The development of educational programs in IT offered at the university can be examined for their relevance to the university's third task. The foci that emerge for this third task are the needs of working life, in particular in the ICT industry, and of the public sector. In this study, the term 'client-centeredness' in planning and implementing IT education refers to activities that take into account the expectations and needs of the target group and/or the requirements of working life.

From a traditional perspective, the goals of IT are research, teaching, and cooperating with other disciplines to develop new multidisciplinary programs and areas of IT-related research. The focal question is: What kind of an operational model might succeed in combining the needs of the business world / public sector with the university's traditional focus on theory? In this light, the goals of the research are as follows:

- to construct an operational model which makes it possible to plan and implement educational programs that serve the educational organization's key clients, such as the public sector and businesses. The programs created must give due consideration to the educational and quality-related goals of the educational organization, e.g., a university. The model is referred to as the client-centered model for the planning and implementation of education.

- to apply the model to the planning and implementation of an educational program and to assess the effectiveness of the model.

The latter goal requires that the model include methods and tools for the different phases of planning as well as for the assessment of the education implemented.

\subsection{Client- or market-centered?}

In an examination of adult education policy in the 1990s, Varhola (1996) identifies changes that have occurred in vocational adult education centres. These have prompted a reform of funding procedures and an emphasis on market-centeredness; i.e., the education is funded by the clients. In such a context, educational organizations must pay sufficient attention to the marketing of their programs and to the planning of content. Tuijman (1992) presents the following as the distinguishing features of the market model of adult education:

- a belief in the economic benefit of the education;

- an emphasis on vocational training;

- a diminishing role for the national government in decisions on education; 
- demand /client needs are taken as the basis for planning;

- the effectiveness of education is measured;

- educational decisions arise through cooperation between corporations. The client-centered model that is being developed as part the present research is close in its goals to the market model of education. The fourth of the features presented above is particularly salient.

The client-centered model differs from the market-centered model in at least the following respects:

- the use of the model in the university context is justified in terms of the university's third task. Rather than concentrating on individual clients or businesses, the model focuses primarily on regional effectiveness as well as the development of cooperation between the university and business life/ the public sector in the region.

- the model takes into account the goals of a university education and attempts to reconcile these with clients' goals.

\section{METHODS}

The principal method used in the present research is constructive research that emphasizes innovation and goals. Here, the object of research is approached from the perspective of action research (Järvinen \& Järvinen, 2001). The research encompasses evaluation research, whose function is to examine the use and impact of the innovation generated, i.e., the operational model.

The following are foci of our action research agenda that emphasizes innovation and goals:

- the combining of the educational goals of the university and the business world and the furthering of the university's regional effectiveness are considered innovative activity.

- the specification of the target situation, i.e., the operational model, is an essential aspect of the research process.

- the researcher has participated actively in the planning and implementation of the programs presented.

The present research involves the planning, implementation and analysis of at least two degree programs using the new operational model. The results will be used to create a theory, i.e. a framework, for the model, and a constructive model of educational planning. The evaluation research will assess the quality and results of the educational programs planned and implemented using the operational model and will determine the impact of the model on the work of the educational organization, the Department of Research Methodology. An literature analysis will be carried out in order to 
ascertain the relevant systems of concepts, methods and planning models. The goal of the analysis and comparison to be conducted is to demonstrate the validity of the model as well as the contribution made by the research. The research will yield new concepts, procedures and techniques for the planning of education in IT.

\section{A CLIENT-CENTERED MODEL}

The construction, use and evaluation of the model will take place in the context of two extensive degree programs in IT being implemented at the Department of Research Methodology. One is the NetCom (Network Competence) project, begun in 2002, the other the SEMEL (Services Management of East Lapland) project, which will begin probably in autumn 2003. Table 1 below summarizes the projects:

Table 1. The NetCom and SEMEL projects

\begin{tabular}{|c|c|c|}
\hline & NetCom & SEMEL \\
\hline Clients & $\begin{array}{l}\text { ICT industry in the Rovaniemi } \\
\text { region, organizations and businesses } \\
\text { making extensive use of ICT, } \\
\text { including the public sector to a } \\
\text { certain extent }\end{array}$ & $\begin{array}{l}\text { The public sector and busi- } \\
\text { ness life in East Lapland }\end{array}$ \\
\hline Funding & $\begin{array}{l}\text { ESF, Finnish Ministry of Education, } \\
\text { corporate and municipal financing }\end{array}$ & $\begin{array}{l}\text { ESF, Finnish Ministry of } \\
\text { Education }\end{array}$ \\
\hline Education & $\begin{array}{l}\text { Education leading to a university } \\
\text { degree, client-centeredcourses } \\
\text { tailored to client needs }\end{array}$ & $\begin{array}{l}\text { Education leading to a uni- } \\
\text { versity degree }\end{array}$ \\
\hline
\end{tabular}

The operational model has been constructed using a heuristic approach;

- the first version of the model is being used in planning and implementing NetCom. Application of the model in NetCom will yield a new, refined version of the model.

- the refined version of the model will be applied in the SEMEL project

\section{THE PRELIMINARY MODEL}

Figure 1 presents a preliminary version of the operating model, which is being applied and refined in the NetCom project. Operational model represents the multidisciplinary research practice (also known as integration 
between different fields of study) and methodological dialogue of applied information technology used in the Department of Research Methodology.

Purposes of the operational model is the multi-methodological research practice, in which:

- Use of the qualitative research methodology and modified method of the IT are combined,

- SSM methodology is applied (Checkland 1981) to the transformation process of the educational organisations.

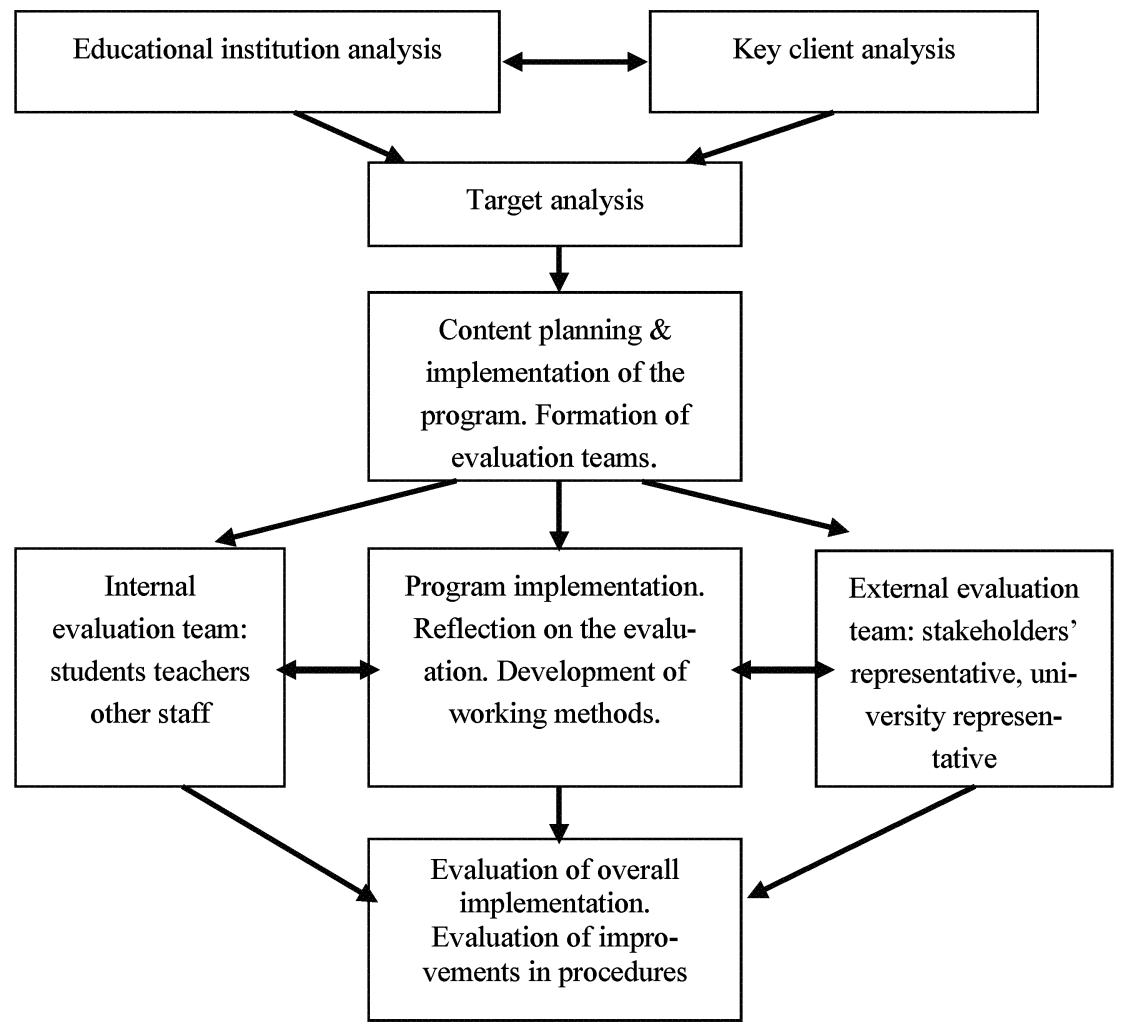

Figure 1. The preliminary version of the operating model

An example of the transformation process is the Department of Research Methodology whose teaching, content of teaching, resource allocation and tasks are strongly influenced by the NetCom and SEMEL projects.

The central concept in the model is the key client, or constituent, who represents the target group for whom the educational program is planned. Key clients may be ICT businesses or university students (or a subset of 
these) or persons on the open market who have a certain know-how /educational profile.

Key client analysis of the NetCom project mapped educational needs and willingness for cooperation in the NetCom project from the ICT organization, new media organizations and organizations making extensive use of IT in the Rovaniemi region. Financial funding was expected of the cooperation partners: in return the NetCom project offered research in the form of a master's thesis. There are seven cooperation partners including all the largest software houses and IT services producers in the Rovaniemi region. Representatives of the Department of Research Methodology and the cooperation partners form an IT cooperation group. The IT cooperation group represents innovative attitude of the operation model. Professionalism, consultation and quality of the education evaluation are the characteristics that describe the IT cooperation group. One aspect of the IT cooperation group is to plan new cooperation projects.

The NetCom project includes both Masters School leading to a university degree and also educational services offered to the clients. The educational services include designing and carrying out of tailored study modules for the clients and also the right to study whole entities.

\section{SUMMARY}

The research described will take place during the period 2003 to 2006. At this writing (February 2003), the NetCom project has begun and its client businesses comprise the key business in the ICT industry in the Rovaniemi region.

The first refinement of the operational model has been carried out, and the division of the model into component phases has also been refined. The content of each phase has been specified in more detail and appropriate methods have been chosen and developed for carrying out the phases.

When evaluating the operational model and the NetCom project, the actual negative experiences aren't. The positive results so far are:

- The NetCom project itself. The project required funding from the enterprises. The operational model created a frame for the concept of cooperation.

- Creating of the network between the university and ICT organisations in the Rovaniemi region. The essential part of the network is the IT cooperation group.

- Study modules tailored for the clients. These study modules enrich teaching at the Department of Research Methodology because students of 
the University of Lapland are also able to attend the courses tailored for the clients.

The goal is that by the end of 2006 the research will provide the university with a model that is applicable to the planning, implementation and evaluation of client-centred IT education. This will be a model that has been developed and validated in two extensive degree programs and will have a significant impact on the development of the activities, teaching and research of the Department of Research Methodology.

\section{REFERENCES}

Checkland, P. (1981). Systems Thinking, Systems Practice. John Wiley \& Sons Ltd. Järvinen, P., \& Järvinen A. (2001). Tutkimustyö metodeista. Opinpaja, Tampere.

Sallinen, A. (2000). Jyväskylän yliopiston avajaispuhe 2000. retrieved 19.06 .03 from $\mathrm{http} / / / \mathrm{www} . j y u . f i / t d k /$ hallinto/rehtori/puhe/avajaispuhe2000.html

Tuijnman A. C. (1992). Paradigm Shifts in Adult Education. in A. Tuijnman (Ed.), Learning Across the Lifespan: Theories, Research, Policies. Oxford: Pergamon Press.

Varmola, T. (1996). Markkinasuuntautuneen koulutuksen aikakauteen? Tampereen yliopisto.

Kasvatustieteiden tiedekunta. Acta Universitatis Tamperensis. Series A. vol. 524.

Virtanen, I. (2002). Yliopistojen kolmas tehtävä. Pole-kuntatieto Oy ja Ilkka Virtanen.

\section{BIOGRAPHY}

Ilkka Kamaja has research interests in the curriculum development. Recent research and development has focused on client-centered education model in the field of Information Technology. Email: ilkka.kamaja@urova.fi. Juha Lindfors' research interests lie in the design and use of e-learning environments for engineering curricula. Recent research and development has focused on developing and implementing a learning environment for Control Engineering that combines new learning methods and ICT tools. Email: juha.lindfors@urova.fi 